\title{
Protective Effect of Phoenix dactylifera-L Extracts against Radiation-Induced Cardio- Toxicity and Some Biochemical Changes in Male Albino Rats
}

\section{S. A. Mangood and A. M. Kamal}

Radiation Protection and Biological Applications Dept., Nuclear Research Centre (NRC), P. No; 13759, Egypt.

\footnotetext{
$\mathrm{T}$ HE ANTIOXIDANT properties of the date palm fruit; Phoenix dactylifera- $L$ in mitigation of cellular injury following free radicals release by ionizing radiation has been investigated. Forty-eight male albino rats divided equally into 6 groups were used in this study. Group 1 (G.1) acted as control, G. 2 received date extract orally ( $4 \mathrm{ml} / \mathrm{kg}$ / day) for 21 days, $\mathrm{G} .3$ was exposed to a single dose of gamma irradiation (6 Gy), G.4 received date extract orally at an identical dose and duration to G.2 and irradiation to G.3, G.5 received the daily date extract for 7 days post irradiation and G.6 received the daily date extract for 21 days before and for 7 days after irradiation.

Heart tissue was examined histologically and biochemical testing for total cholesterol (TC), triglycerides (TG), high and low density lipoprotein-cholesterol (HDL-C and LDL-C), creatine kinase $(\mathrm{CK})$, creatine kinase-MB (CK-MB) and lactate dehydrogenase (LDH) was performed for each rat group.

Data from the investigation showed that gamma irradiation caused histopathological damage to the heart tissue and disturbances in most parameters related to cardiac function. Administration of date extracts pre-irradiation provided evidence of a potential protective effect against irradiation hazard.

Keywords: Palm fruits, gamma irradiation, cardio toxicity, rats.
}

Radiation injury to living cells is to a large extent, due to oxidative stress (Mohamed et al., 2007). Reactive oxygen species (ROS) are known to play multiple roles in physiological and pathological states and are constantly produced in living organisms (Tawfik et al., 2006) The highly reactive superoxide radical and hydrogen peroxide may be toxic to cells by direct attack at the molecular level or indirectly by generating secondary reactive species such as the hydroxyl radical. These radicals may cause oxidative damage 
virtually to any bimolecular structure (Zahran et al., 2007). Radio-protectors aim to control the initial damage induced in the biological system at the molecular level before other physiological or micro-anatomical changes occur. This hypothesis is based on the use of chemicals that prevent the development of radiation injury in exposed organisms by mitigation of radionuclide absorption through activation of the free radical scavenging system (Cherupally et al., 2001). The efficiency of the radio protective agents is greatly dependent on their chemical properties, duration of treatment and post-irradiation time elapse after the application radioprotection.

An ideal radio-protective agent should be active, rapidly absorbed and easily distributed in the body tissues. It must be without side effects or at least with minimal toxicity which gives insurance that no cumulative consequences could be expected from their repeated usage (Slyshenkov et al., 1999).

Fruits of the date palm are well known as staple food and contains a high percentage of carbohydrate (total sugars, 44-88\%), fats (0.2-0.5\%), 15 salts, minerals, proteins (2.3-5.6\%), vitamins as vitamin $A$, vitamin $C$, vitamins $B_{1}$ (thiamine), $\mathrm{B}_{2}$ (riboflavin), nicotinic acid (niacin) and a high percentage of dietary fibre (6.4-11.5\%). The flesh of dates contains $0.2-0.5 \%$ oil, whereas the seed contains 7.7-9.7\% oil (Al-Shahib and Marshall, 2003). The important of palm oil are fatty acids which have shown to possess anti-bacterial, antiprotozoal as well as anti-cancer activities (Komarasamy and Sekaran, 2012).

Various parts of the plant are widely used in traditional medicine for the treatment of various disorders, including memory disturbances, fever, inflammation, paralysis loss of consciousness and nervous disorders (Vyawahare et al., 2010). Extracts of the dates fruit are reported to possess antiulcer, anticancer, hepatoprotective, anti-mutagenic, aphrodisiac, anti-inflammatory, antimicrobial, antigen-toxic, antihyperlipidemic, nephroprotective and antioxidant activities (Vyawahare et al., 2010).

The main purpose of the present study is to investigate the potential role of date extract in ameliorating radiation-induced cardio toxicity and related biochemical parameters in male albino rats and assess maximum benefit of using this radio-protectors pre, post or pre and post irradiation.

Egypt. J. Rad. Sci. Applic., Vol. 24, No. 2 (2011) 


\section{Materials and Methods}

Forty-eight male albino rats (Rattus Rattus) used in the present study were obtained from the breeding unit of NCR. Rats were housed in metal cages with adequate ventilation and under normal climatic conditions. Rats were categorized into six groups; each group was consisted of eight rats with body wt ranging between $120-150 \mathrm{~g}$.

Animals were irradiated using a gamma-Co-60 source (Middle Eastern Regional Radioisotope Centre for Arab, Giza, Egypt). This cobalt source offers a dose rate of $0.53 \mathrm{~Gy} / \mathrm{min}$. and a total dose of $6 \mathrm{~Gy}$ was used in the study.

Fresh Siwa date fruit was obtained (Agriculture Research Centre, Giza. Egypt). The flesh was manually separated from the pits, soaked in cold distilled water at a ratio of 1:3 (wt to volume) for $24 \mathrm{~h}$ prior to use. Rats were treated orally with this suspension at a dose of $4 \mathrm{ml} / \mathrm{kg}$ body wt (Al-Qarawi et al., 2005) via an intubation's tube.

Forty eight rats were classified into six groups:

G.1: Rats were kept on a standard commercial diet without any additional treatment.

G.2: Rats received a daily oral dose of date extract at $4 \mathrm{ml} / \mathrm{kg} /$ day.

G.3: Rats were exposed to a single dose of 6 Gy of gamma radiation.

G.4: Rats received a daily oral dose of date extract at $4 \mathrm{ml} / \mathrm{kg} /$ day for 21 days before irradiation with a single dose $6 \mathrm{~Gy}$ of gamma radiation.

G.5: Rats received a daily oral dose of date extract at $4 \mathrm{ml} / \mathrm{kg} /$ day/day for 7 days after irradiation with a single dose 6 Gy of gamma radiation.

G.6: Rats received a daily oral dose of date at $4 \mathrm{ml} / \mathrm{kg} /$ day for 28 days ( 21 days before irradiation and daily for 7 days after irradiation).

At the end of the experiment, animals were sacrificed after $12 \mathrm{~h}$ : fasting blood samples were collected after one day and sera separated. Hearts were retained and kept in 10\% buffered formaldehyde before staining with eosin and haematoxylin (H\&E) and examined at X200 by ordinary microscope.

Egypt. J. Rad. Sci. Applic., Vol. 24, No. 2 (2011) 
Serum TC was determined by an enzymatic spectrophotometrically method according to Ellefson and Caraway (1976) and serum TG was measured according to Fossati and Prencipe (1982), HDL-C content was assayed spectrophotometrically according to the method of Lopes-Virella et al. (1977) and LDL-C was evaluated according to Friedewald et al. (1972).

CK and CK-MB were determined according to the method of Tielz (1999) and of LDH activity was determined according to method of Henderson and Moss (2001).

Data was statistically analyzed using the general linear models procedure of Costat program (1986) and presented as mean \pm S. E. The analysis of variance (ANOVA) was performed according to Snedecor and Cochran (1989). Significant differences between means were determined as described by Duncan (1955).

\section{Results}

Microscopically, hearts from rats in G.1 and G.2 revealed normal cardiac myocytes (Fig. 1-2). Heart from irradiated rats G.3 (Fig. 3) showed intramuscular oedema, few inflammatory cells infiltration and focal necrosis of cardiac myocytes (Fig. 4) as well as focal myolysis of myocytes (Fig. 5). Sections from G.4 (Fig. 6) and G.6 (Fig. 8) revealed no histopathological changes. However, heart from G.5 showed Zenker's necrosis of sporadic myocytes (Fig. 7).

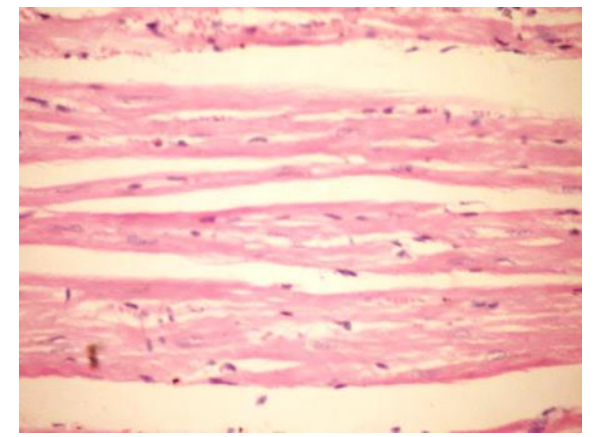

Fig. 1. Hearts of G.1 showing normal cardiac myocytes.

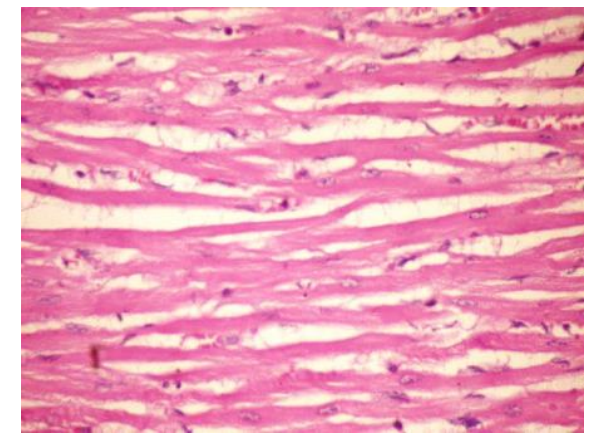

Fig. 2. Heart of G. 2 showing no histopathological changes.

Egypt. J. Rad. Sci. Applic., Vol. 24, No. 2 (2011) 


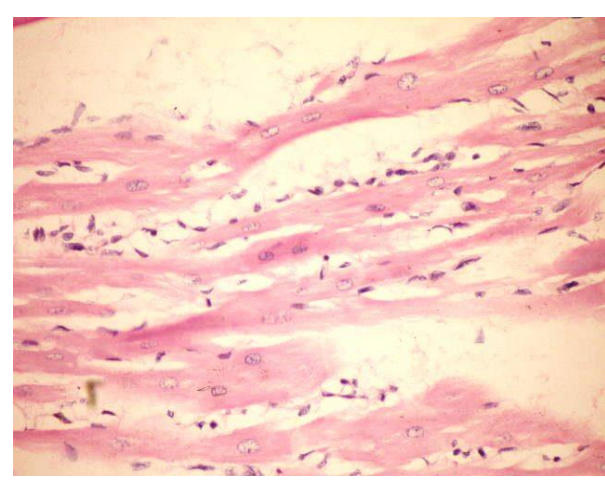

Fig. 3. Heart of rats G. 3 showing intermuscular oedema.

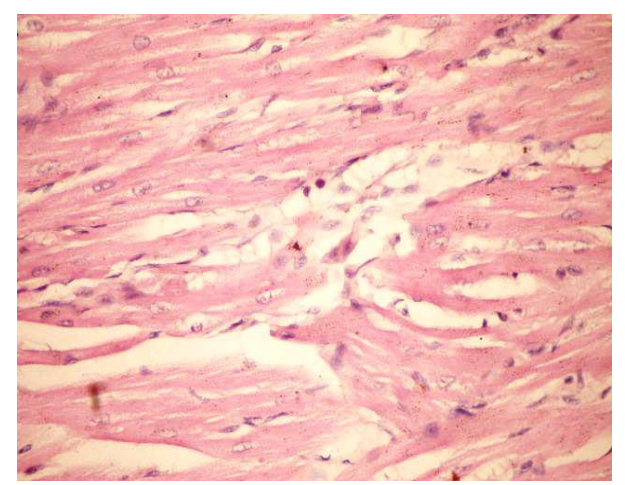

Fig. 5. Heart of G. 3 showing focal myolysis.

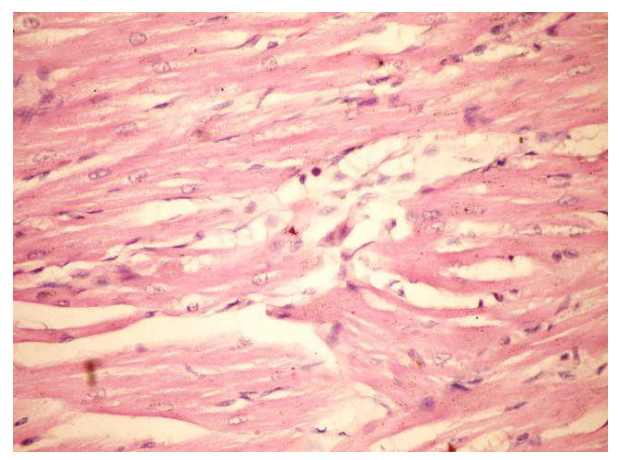

Fig. 7. Heart of G. 5 showing Zenker's necrosis of sporadic myocystes.

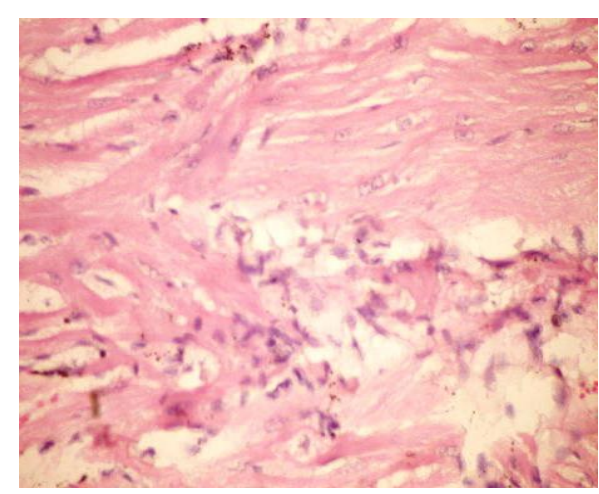

Fig. 4. Heart of rat G. 3 showing focal necrosis of cardiac myocytes.

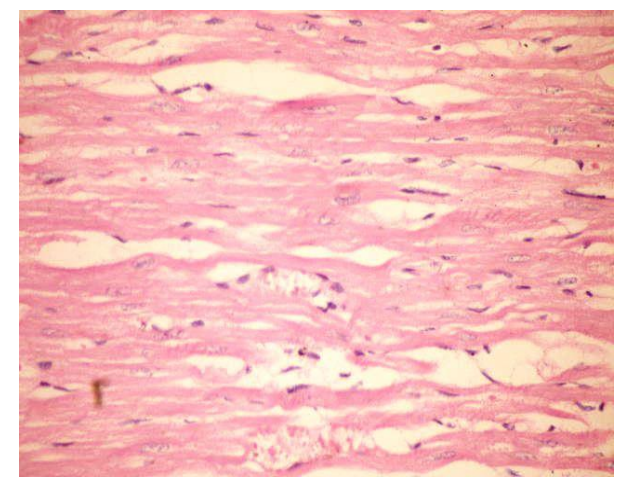

Fig. 6. Heart of G. 4 showing no hisopathological changes

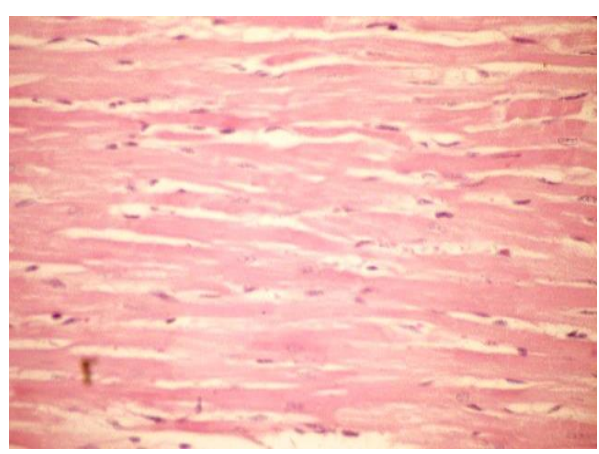

Fig. 8. Heart of G. 6 showing no hisopathological changes.

Egypt. J. Rad. Sci. Applic., Vol. 24, No. 2 (2011) 
Table 1. shows the effect of date palm extract on the serum levels of TC, TG, LDL-C and HDL-C in irradiated male albino rats. The animals in G.3 \& G.5 showed a significant increase in the level of TC, TG and LDL-C and significant decrease in HDL-C while no significant changes in G.4 \& G.6 compared to the corresponding control values in G.1 were observed.

TABLE 1. Effect of the date palm extract on the serum level of TC, TG, HDL-C and LDL-C in irradiated male albino rats.

\begin{tabular}{|c|c|c|c|c|c|}
\hline Group & $\begin{array}{c}\text { TC } \\
\mathrm{mg} / \mathrm{dl}\end{array}$ & $\begin{array}{c}\text { TG } \\
\mathrm{mg} / \mathrm{dl}\end{array}$ & $\begin{array}{c}\text { HDL-C } \\
\mathrm{mg} / \mathrm{dl}\end{array}$ & $\begin{array}{c}\text { LDL-C } \\
\mathrm{mg} / \mathrm{dl}\end{array}$ & LDL-C/ HDL-C \\
\hline G. 1 & $77.13^{\mathbf{c}} \pm 2.26$ & $96.84^{\mathbf{c}} \pm 2.70$ & $30.45^{\mathbf{a}} \pm 0.30$ & $27.31^{\mathbf{c}} \pm 1.42$ & 0.90 \\
\hline G. 2 & $79.31^{\mathbf{b} \mathbf{c}} \pm 1.55$ & $102.50^{\mathbf{c}} \pm 3.02$ & $29.01^{\mathbf{a}} \pm 1.96$ & $29.80^{\mathbf{c}} \pm 1.02$ & 1.01 \\
\hline G. 3 & $100.35^{\mathbf{a}} \pm 1.40$ & $141.57^{\mathbf{a}} \pm 5.51$ & $20.18^{\mathbf{b}} \pm 1.21$ & $51.86^{\mathbf{a}} \pm 4.09$ & 2.57 \\
\hline G. 4 & $77.85^{\mathbf{c}} \pm 0.35$ & $101.82^{\mathbf{c}} \pm 5.77$ & $30.38^{\mathbf{a}} \pm 1.58$ & $27.10^{\mathbf{c}} \pm 2 . .^{\mathbf{q}}$ & 0.89 \\
\hline G. 5 & $84.20^{\mathbf{b}} \pm 1.11$ & $125.59^{\mathbf{b}} \pm 4.15$ & $25.79^{\mathbf{b}} \pm 1.22$ & $33.29^{\mathbf{b}} \pm 0.9 \varepsilon$ & 1.29 \\
\hline G. 6 & $79.27^{\mathbf{b}} \pm 3.29$ & $98.49^{\mathbf{c}} \pm 4.62$ & $29.93^{\mathbf{a}} \pm 0.64$ & $29.64^{\mathbf{c}} \pm 1.73$ & 0.99 \\
\hline
\end{tabular}

Each value represents means \pm S. E. M. of 8 rats. a, b, c \& d values in the same row with different superscript differ significantly $(\mathrm{P}<0.05)$

Table 2. showed the effect of date palm extract on the activities of CK, CK-MB and LDH in male albino rats. A significant increase in the activity of serum CK, CK-MB and LDH in animals of G. 3 \& G.5 occurred and there were no significant changes in groups G.4 \& G.6 compared to their corresponding control values in G.1.

TABLE 2. Effect of the date palm extract on activities of CK, CK-MB \& LDH in irradiated male albino rats.

\begin{tabular}{|c|c|c|c|}
\hline Group & CK $(\mathrm{U} / \mathrm{ml})$ & CK-MB $(\mathrm{U} / \mathrm{ml})$ & LDH $(\mathrm{U} / \mathrm{ml})$ \\
\hline G. 1 & $130.56^{\mathbf{c}} \pm 1.08$ & $74.42^{\mathbf{b c}} \pm 3.54$ & $69.45^{\mathbf{b}} \pm 4.49$ \\
\hline G. 2 & $128.04^{\mathbf{c}} \pm 1.95$ & $68.41^{\mathbf{c}} \pm 1.50$ & $68.10^{\mathbf{b}} \pm 3.920$ \\
\hline G. 3 & $227.76^{\mathbf{a}} \pm 17.18$ & $97.42^{\mathbf{a}} \pm 2.95$ & $94.71^{\mathbf{a}} \pm 4.31$ \\
\hline G. 4 & $132.59^{\mathbf{c}} \pm 1.29$ & $72.67^{\mathbf{b}^{\mathbf{c}}} \pm 3.05$ & $67.00^{\mathbf{b}} \pm 3.79$ \\
\hline G. 5 & $170.61^{\mathbf{b}} \pm 4.68$ & $79.23^{\mathbf{b}} \pm 1.43$ & $87.54^{\mathbf{a}} \pm 4.72$ \\
\hline G. 6 & $135.81^{\mathbf{c}} \pm 2.24$ & $72.24^{\mathbf{b c}} \pm 2.34$ & $68.92^{\mathbf{b}} \pm 3.68$ \\
\hline
\end{tabular}

Legends as in Table 1.

\section{Discussion}

Exposure to ionizing radiation is accompanied with a wide array of biological responses (Little, 2007). The speed, character and appearance of radiation effects is also depend on dose and mode of contact with the body.

Egypt. J. Rad. Sci. Applic., Vol. 24, No. 2 (2011) 
Tissue damage results from the energy transfer causing excitation, ionization or formation of free radicals in molecules of the encountered tissues (ASTDR, 1999). In the present study, histopathology of heart tissue from G.3 showed intramuscular oedema. Several years after irradiation and manifestation include accelerated atherosclerosis, pericardial and myocardial fibrosis, conduction abnormalities and injury to cardiac valves (Boerma and Hauer-Jensen, 2011). Cell membranes are rich sources of polyunsaturated fatty acids (PUFA) and incorporation of PUFA in membrane phospholipids influences membrane stabilization by modulating the fluidity of myocardial membrane (Rezk et al, 2009). However, it is also important to note that the presence of highly unsaturated PUFA makes the myocardial membrane easily susceptible to oxyradical induced necrotic damage resulting in increased release of diagnostic makers into the blood as observed in the present study. The presence of PUFA in cell membrane plays a major role in inhibition of cell volume reduction by modulating the elasticity of plasma membrane (Sanchez-Olea et al., 1995). Cell volume affects the most basic processes of cell function and as such exerts an important role in the onset severity and outcome of myocardial infarction. Fruit and vegetable consumption has been shown to reduce the risk of chronic diseases such as cancer (Block et al., 1992) and heart disease (Rimm et al., 1996) in multiple epidemiology studies.

Evidence has shown that hyperlipidemia and oxidative stress increases the risk of heart diseases (Madamanchi and Runge, 2007) Similarly the chronic overproduction of ROS leads to increased oxidation of LDL-C promoting the formation of plaque on cardiovascular vessels (Klebanove et al., 1998) causing arteriosclerosis which increases the risk of stroke and heart failure (Burcham, 2002). In the same way, exposure to radiation resulted in oxidative stress (Dasgupta et al., 1997) and consequently, oxidative modifications take place in cellular molecules (Romero et al., 1998). The subsequent structural and ultrastructural damage may lead to cardiovascular complications and cardiac related death.

The results obtained in the present study showed that, exposure of rats to gamma radiation resulted in significant biochemical disturbances associated with significant histological change. Our data showed that whole body gamma

Egypt. J. Rad. Sci. Applic., Vol. 24, No. 2 (2011) 
exposure of rats by a single dose of $6 \mathrm{~Gy}$ resulted in hyperlipidaemia manifested by significant increase in the levels of serum TC, TG, LDL-C and a significant decrease in HDL-C. A good correlation was established between elevation of LDL-C and the decrease in HDL-C leading to high risk of the exposed animals to radiation damage. LDL-C could be oxidized in essence becoming a free radical itself (oxysterol). These results agree with the previous finding by Soliman (1997) and Yacoub (2004). Roushdy et al. (1997) who found that the elevation in cholesterol level might be due to disturbance in the metabolism of bile pigments and lipid due to liver damage resulting from radiation exposure. Kafafy and Ashry (2001) explained that the increase in serum cholesterol level could be due to the decrease in lecithin cholesterol acyltransferase leading to a decrease in cholesterol estrification. The increase in TG level of irradiated rats may be related to inhibition of lipoprotein lipase activity in adipose tissue between 24 and 48 h post-irradiation (Sedláková et al., 1977) and these results are agreement with Soliman (1997). Radiation exposure imposes an increased requirement for fat, which could result in mobilization of peripheral fat exiting tissue and its transportation by the blood.

CK is an isoenzyme found in cells with intermittent high- energy requirements, mainly muscle tissues (Wallimann, 1996). LDH is found in cells of almost all the body tissues and following tissue injury, particularly heart, the enzyme is released into the blood stream. The increase of serum enzyme levels may be due to alteration in the dynamic permeability of membranes induced by ionizing radiation; allowing leakage of biological active material out of the injured cell (MacWilliam and Bhakthan, 1976). Increased activity of blood LDH may be due to the irradiation enhancement of enzyme movement from its sub-cellular production sites to the extra-cellular fluid and consequently to blood (Fahim et al., 1993). In the present study exposure to ionizing radiation caused highly significant increase in CK, CK-MB and significant increase in LDH which agrees with Gharib (2007) who reported that gamma irradiation showed a significant increase in the level of serum enzyme CK, CK-MP and LDH due to the damage in the heart. The results are also in accordance with those previously reported by Ramadan et al. (2003), Srivastava et al. (2002) and Yanardag et al. (2001).

Egypt. J. Rad. Sci. Applic., Vol. 24, No. 2 (2011) 
In the present study pre-irradiation and pre and post irradiation intake of date extract had a protective role whist post irradiation alone gave less protective effect which may be related to the short duration or timing of the treatment with date extract.

The antioxidant activity of date water extract is attributed to a wide range of phenolic compounds including p-coumaric ferulic, sinapic acids, flavonoids and procyanidins ( $\mathrm{Gu}$ et al., 2003), Polyphenols in the water extract was higher significantly compared to the alcohol extract (Saleh et al., 2011), higher iron chelation ability, 2, 2-diphenyl-1-picrylhydrazyl (DPPH) scavenging activity and antioxidant activities (Ahmed and Rocha, 2009 and Saleh et al., 2011). Saleh et al. (2011) reported that date fruit can be considered a rich source of hydrophilic antioxidant, and this reducing property is generally associated with the presence of polyphenols specifically flavanols. Abundant evidence exists for a beneficial effect of phenol antioxidant on heart disease (Vinson et al., 2005). An early step in atherosclerotic lesion formation is oxidation of LDL-C and very low -density lipoprotein (Steinberg et al., 1989). Increased attention has been paid to the role of natural antioxidants, mainly phenolic compounds, which may have more antioxidant activity than vitamins $\mathrm{C}, \mathrm{E}$, or $\beta$-carotene (Haslam, 1996). Hertog et al. (1993) reported that polyphenolic antioxidants such as flavonoids from fruit and vegetable components are protective for heart disease.

It could be concluded that timely, nutritional support with date palm extract before irradiation gave a protective effect against radiation induced acute cardiac damage in male albino rats which may result from the beneficial effect of phenol antioxidant on the development of heart disease.

\section{Acknowledgement}

The authors acknowledge the sincere help of Dr. Kawkab Abdel Aziz Ahmed, collage of Veterinary Medicine, Cairo University, Egypt, in the examination of the histological section.

\section{References}

Ahmed, S. H. and Rocha, J. B. (2009) Antioxidant properties of water extracts for the Iraq plants. Modern Appl. Sci., 3, 161.

Egypt. J. Rad. Sci. Applic., Vol. 24, No. 2 (2011) 
Al-Qarawi, A. A., Abdel-Rahman, H., Ali, B. H., Mousa, H. M., El-Mougy. S. A. (2005) The Ameliorative effect of dates (Phoenix Dactylifera L.) on ethanolinduced gastric ulcer in rats. J. Ethnopharmacol., 98, 313.

Al-Shahib, W. and Marshall, R. J. (2003) The Fruit of the date palm: Its possible use as the best food for the future. Int. J. Food Sci. Nutr., 54, 247.

ASTDR, Agency for Toxic Substance and Disease Registry (1999) Toxicological profile for ionizing radiation. Atlanta, G.A.: Agency for Toxic Substance and Disease Registry. U.S. Department of Health and Human and Human Services. Public Health Service.

Block, G., Patterson, B. and Subar, A. (1992) Fruit, vegetables and cancer prevention: a review of the epidemiological evidence. Nutr. Cancer, $\mathbf{1 8}, 1$.

Boerma, M and Hauer-Jensen, M. (2011) Review article Preclinical research into basic mechanisms of radiation-induced heart disease. Cardiol. Res. Practice, 10,1 .

Burcham, P. C., Kaminskas, L. M., Fontaine, F. R., Petersen, D. R. and Pyke, S. M. (2002) Aldehyde-sequestering drugs: tools for studying protein damage by lipid peroxidation products. Toxicology, 181-182, 229.

Cherupally, K. K., Dillip, K. and Taisei, N. (2001) The potential radioprotective role of selenium on gamma irradiated rats' salivary glands. J. Radiat. Res., 42, 21.

Costat 3.03 (1986) Copyright Cohort Software All Rights Reserved. P. O. Box; 1149, Berkeley, CA 94701.

Dasgupta, A., Malhotra, D., Levy, H., Marcadis, D., Blackwell, W. and Johnston, D. (1997) Decreased total antioxidant capacity but normal lipid hydroperoxide concentrations in sera of critically ill patients. Life Sci., 60 , 335.

Duncan, D. B. (1955) Multiple Range and Multiple F-Test. Biocmetrics, 11, 1.

Ellefson, R. D. and Caraway, W. T. (1976) Fundamentals of Clinical Chemistry Ed. Tietiz NW: p506.

Fahim, F. A., Roshdy, H. M., Yousri, R. M. and Abady, M. I. (1993) Some biochemical aspects of the protective effect of strontium chloride on gammairradiated rats. Biometals, 6,163.

Fossati, P. and Prencipe, L. (1982) Serum triglycerides determined colorimetrically with an enzyme that produces hydrogen peroxide. Clin. Chem., 28, 2077.

Friedewald, W. T., Levy, R. I. and Fredrickson, D. S. (1972) Estimation of the concentration of low-density lipoprotein cholesterol in plasma, without use of the preparative ultracentrifuge. Clin. Chem., 18, 499.

Gharib, O. A. (2007) Does kombucha tea reduce the damage induced by radiation exposure?. Egypt. J. Rad. Sci. Applic., 20, 141.

Egypt. J. Rad. Sci. Applic., Vol. 24, No. 2 (2011) 
Gu, L., Kelm, M. A., Hammerstone, J. F., Beecher, G., Holden, J., Haytowitz, D. and Prior, R. L. (2003) Screening of foods containing proanthocyanidins and their structural characterization using LC-MS/MS and thiolytic degradation. J. Agric. Food Chem., 51, 7513.

Haslam, E. (1996) Natural polyphenols (Vegetable Tannins) as drugs: possible modes of action. J. Nat. Prod., 59, 205.

Henderson, A. R. and Moss, D. W. (2001) Tietz Fundamentals of Clinical Chemistry. $5^{\text {th }}$ Ed., Burlis, C. A. and Ashwood. E.R. (ed.) Philadelphia, USA, p.352.

Hertog, M. G. L, Feskens, E. J. M, Hollman, P. C. H., Katan, M. B. and Kromhout, D. (1993) Dietary antioxidant flavonoids and risk of coronary heart disease: the Zutphen Elderly Study. Lancet, 342, 1007.

Kafafy, Y. A. and Ashry, O. M. (2001) Antioxidative potential of parsly on gamma irradiated rats. Egypt. J. Rad. Sci. Applic., 14, 25.

Klebanov, G. I., Teselkin, Yu. O., Babenkova, I. V., Lyubitsky, O. B., Rebrova, O. Yu., Boldyrev, A. A. and Vladimirov, Yu. A. (1998) Effect of carnosine and its components on free-radical reactions. Member. Cell Biol., 12, 89.

Komarasamy, T. V. and Sekaran, S. D. (2012) The anti-proliferative effects of a palm oil-derived product and its mode of actions in human malignant melanoma mewo cells. J. oleo Sci., 61, 227.

Little, J. B. (2007) Nontargeted effects of ionizing radiation: implications for low-dose exposures. Radiat. Biol. Radioecol., 47, 262.

Lopes-Virella, M. F, Stone, P., Ellis, S. and Colwell, J. A. (1977) Cholesterol determination in high-density lipoproteins separated by three different methods. Clin. Chem., 23, 882.

MacWilliam, L. D. and Bhakthan, N. M. (1976) Radiation-induced enzyme efflux from rat heart: sedentary animals. Recent Adv. Stud. Cardiac. Struct. Metab., 9, 447.

Madamanchi, N. R. and Runge, M. S. (2007) Mitochondrial dysfunction in atherosclerosis. Circ. Res., 100, 460.

Mohamed, M. I., Ali, S. E. and Haggag, A. M. (2007) Radioprotective effect of Lycopene in gamma irradiated albino rats. Isotope \& Rad. Res., 39, 927.

Ramadan, L. A., Ahmed, M. M., Mostafa, T. M., Ismaeel, H. A. and Amin, N. E. (2003) Propionly L-carnitine as a potential protective agent against radiationinduced cardiotoxicity. Egypt. J. Rad. Sci. Applic., 16, 436.

Rezk, R. G., Yacoub, S. F. and Abd El Aziz, N. (2009) Squalene Modulates Radiation-induced structural, ultrastructural and biochemical changes in cardiac muscles of male albino rats. Isotope \& Rad. Res., 41, 1705.

Egypt. J. Rad. Sci. Applic., Vol. 24, No. 2 (2011) 
Rimm, E. B, Ascherio, A., Giovannucci, E, Spiegelman, D, Stampfer, M. J. and Willett, W. C. (1996) Vegetable, fruit, and cereal fiber intake and risk of coronary heart disease among men. JAMA., 275, 447.

Romero, F. J., Bosch-Morell, F., Romero, M. J., Jareño, E. J., Romero, B., Marín, N. and Romá, J. (1998) Lipid peroxidation products and antioxidants in human disease. Environ. Health Perspect., 106, 1229.

Roushdy, H., Abdel-Hamid, F. and Abu-Ghadir, A. R. (1997) Impairment of liver and kidney functions in gamma irradiated rats suffering from pesticide toxicity. Isotope \& Rad. Res., 29, 11.

Sanchez-Olea, R., Morales-Mulia, M., Moran, J. and Pasantes-Morales, H. (1995) Inhibition by polyunsaturated fatty acids of cell volume regulation and osmolyte fluxes in astrocytes Am. J. Physiol., 269, C96.

Saleh, E. A., Tawfik, M. S. and Abu-Tarboush, H. M. (2011) Phenolic Contents and Antioxidant Activity of Various Date Palm (Phoenix dactylifera L.), Fruits from Saudi Arabia. Food Nut. Sci., 2, 1134.

Sedláková, A., Ahlers, I., Ahlersová, E, Malátová, Z., Paulíková E. and Praslicka, M. (1977) The dynamics of changes in serum lipids during continuous irradiation of rats. Folia Biol., 23, 291.

Slyshenkov, V. S., Omelyanchik, S. N., Moiseenok, A. G., Petushok, N. E. and Wojtczak, L. (1999) Protection by pantothenol and beta-carotene against liver damage produced by low-dose gamma radiation. Acta Biochim.. Pol., 46, 239.

Snedecor, G. W. and Cochran, W. G. (1989) "Statistical Methods." $8^{\text {th }}$ ed. Ames, Iowa State Univ. Press (Iowa U.S.A).

Soliman, S. M. (1997) Biochemical and histological studies on lipid pattern in blood and cardio-vascular system as affected by dietary fact intake and/or whole body radiation exposures. PhD Thesis, Faculty of Science, Cairo Univ. Egypt.

Srivastava, M., Chandra, D. and Kale, R. K. (2002) Modulation of radiation-induced changes in the xanthine oxidoreductase system in the livers of mice by its inhibitors. Radiat. Res., 157, 290.

Steinberg, D., Parthasarathy, S., Carew, T. E., Khoo, J. C. and Witztum, J. L. (1989) Beyond cholesterol. Modifications of low-density lipoprotein that increase its atherogenicity. N. Engl. J. Med., 321, 1196.

Tawfik, S. S., Abbady, M. I., Zahran, A. M. and Abouelalla, A. M. K. (2006) Therapeutic efficacy attained with thyme essential oil supplementation throughout $\gamma$-irradiated rats. Egypt. J. Rad. Res. Applic., 19, 1.

Tietz, N. W. (1999) Textbook of Clinical Chemistry $3^{\text {rd }}$ edition Burtis CA, Ashwood ER. WB Saunders Company. Philadelphia, PA, P.703.

Egypt. J. Rad. Sci. Applic., Vol. 24, No. 2 (2011) 
Vinson, J. A., Zubik, L., Bose, P., Samman, N. and Proch, J. (2005) Dried fruits: excellent in vitro and in vivo antioxidants. J. Am. Coll. Nutr., 24, 44.

Vyawahare, N. S., Pujari R. R.., Rajendran R., Khsirsagar, A. D., Ingawale, D. K. and Patil, M. N. (2010) Neurobehavioral effects of Phoenix in mice. $J$. Young Pharm., 1, 225.

Wallimann, T. (1996) 31P-NMR-measured creatine kinase reaction flux in muscle: a caveat!. J. Muscle Res. Cell Motil., 17, 177.

Yacoub, F. S. (2004) PhD Thesis, Faculty of Science, Ain Shams Univ. Egypt.

Yanardag, R., Bolkent, S. and Kizir, A. (2001) Protective effects of DL-alfatocopherol acetate and sodium selenate on the liver of rats exposed to gamma radiation. Biol. Trace Elem. Res., 83, 263.

Zahran, A. M., Omran, M. F., Mansour, S. Z and Ibrahim, N. K. (2007) Effectiveness of carthamus tinctorius L. in the restitiution of lipid composition in irradiated rats. Egypt. J. Rad. Res. Applic., 20, 75.

(Received: 21/03/2012;

accepted: 16/05/2012)

Egypt. J. Rad. Sci. Applic., Vol. 24, No. 2 (2011) 


$$
\begin{aligned}
& \text { التأثير الوقائي لخلاصة التمر علي تسمم القلب لذكور الجرذان البيضـاء }
\end{aligned}
$$

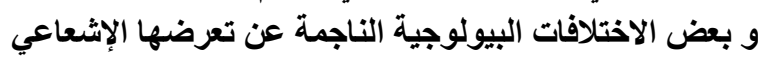

$$
\begin{aligned}
& \text { شادية عبد الستار منجود ، و أمسال محمد كمال }
\end{aligned}
$$

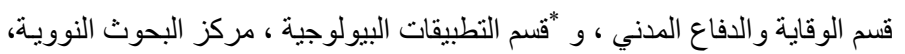

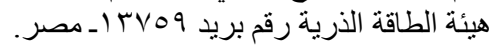

تم در اسة فاعلية مستخلص ثمرة التمر في الوقاية من أضرار الثوارد الحرة

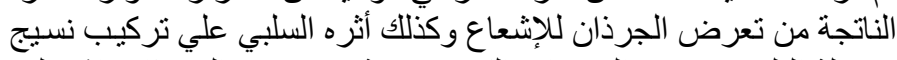

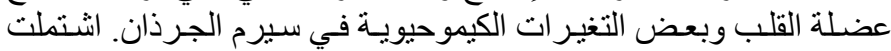

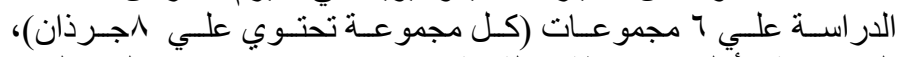

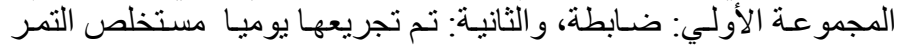

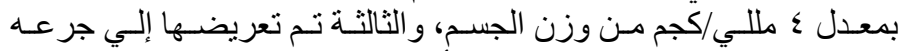

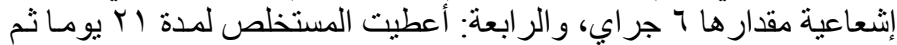

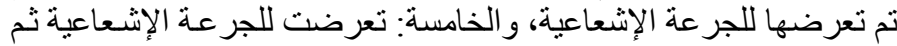

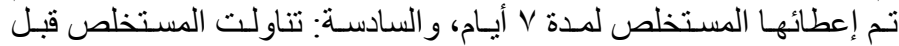

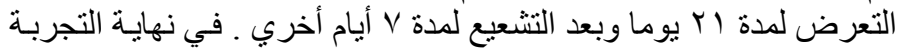

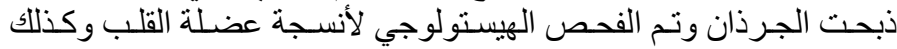

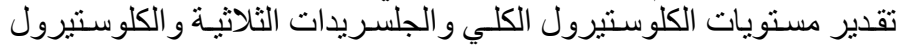

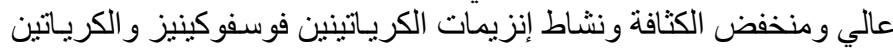

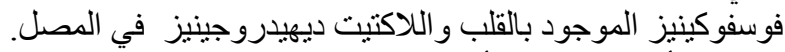

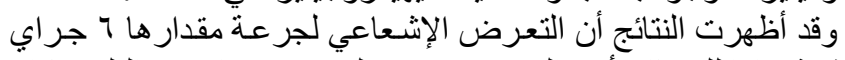

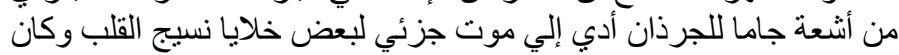

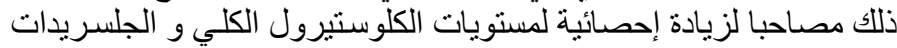

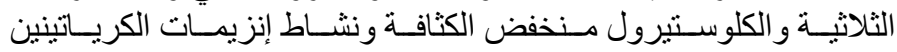

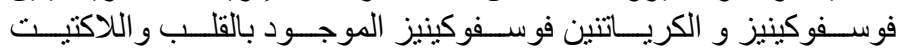
ديهيدروجينيز في المصل. و انخفاض ملحوظ في مستوي الكلوستيرول عالي

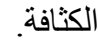

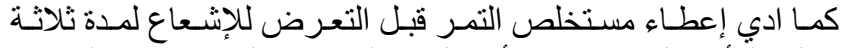

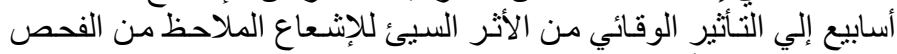

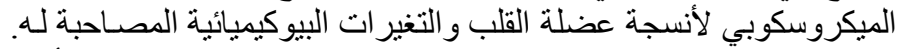

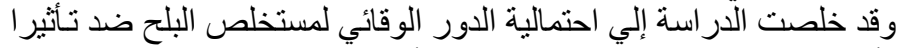

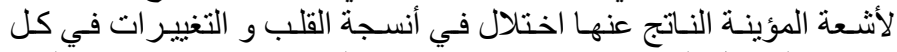

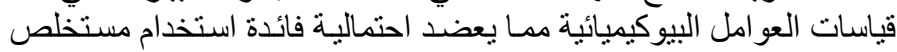
البلح كوسيلة وقائية قبل التعرض الإشيائة الشعاعي. 